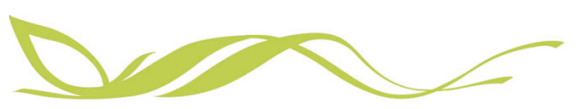

COMMUNICATIONS

EARTH\&ENMRONMENT

ARTICLE

https://doi.org/10.1038/s43247-020-00020-7 OPEN

\title{
Increased extreme precipitation challenges nitrogen load management to the Gulf of Mexico
}

Chaoqun Lu (10 ${ }^{1 凶}$, Jien Zhang (10) ${ }^{1}$, Hanqin Tian (10 ${ }^{2}$, William G. Crumpton (1) ${ }^{1}$, Mathew J. Helmers ${ }^{3}$, Wei-Jun Cai (1) ${ }^{4}$, Charles S. Hopkinson ${ }^{5}$ \& Steven E. Lohrenz ${ }^{6}{ }^{6}$

Although the hypoxia formation in the Gulf of Mexico is predominantly driven by increased riverine nitrogen $(\mathrm{N})$ export from the Mississippi-Atchafalaya River basin, it remains unclear how hydroclimate extremes affect downstream $\mathrm{N}$ loads. Using a process-based hydro-ecological model, we reveal that over $60 \%$ of the land area of the Basin has experienced increasing extreme precipitation since 2000 , and this area yields over $80 \%$ of $\mathrm{N}$ leaching loss across the region. Despite occurring in $\sim 9$ days year ${ }^{-1}$, extreme precipitation events contribute $\sim 1 / 3$ of annual precipitation, and $\sim 1 / 3$ of total $N$ yield on average. Both USGS monitoring and our modeling estimates demonstrate an approximately $30 \%$ higher annual $\mathrm{N}$ load in the years with extreme river flow than the long-term median. Our model suggests that $\mathrm{N}$ load could be reduced by up to $16 \%$ merely by modifying fertilizer application timing but increasing contribution of extreme precipitation is shown to diminish this potential.

\footnotetext{
${ }^{1}$ Department of Ecology, Evolution, and Organismal Biology, lowa State University, Ames, IA 50011, USA. ${ }^{2}$ International Center for Climate and Global Change Research and School of Forestry and Wildlife Sciences, Auburn University, Auburn, AL 36849, USA. ${ }^{3}$ Agricultural and Biosystems Engineering, lowa State University, Ames, IA 50011, USA. ${ }^{4}$ School of Marine Science and Policy, The University of Delaware, Newark, DE 19716, USA. ${ }^{5}$ Department of Marine Sciences, University of Georgia, Athens, GA 30602, USA. ${ }^{6}$ School for Marine Science and Technology, University of Massachusetts-Dartmouth, New Bedford, MA 02744, USA. ${ }^{凶}$ email: clu@iastate.edu
} 
$\mathrm{T}$ he Mississippi and Atchafalaya rivers together contribute $\sim 80 \%$ of the freshwater discharge and $\sim 90 \%$ of total $\mathrm{N}$ export from the United States to the Gulf of Mexico ${ }^{1}$. Riverine N flux from the Basin is an important contributor to the formation of the hypoxic zone (dissolved oxygen $<2 \mathrm{mg} \mathrm{L}^{-1}$ ) in the northern Gulf of Mexico each summer ${ }^{2-4}$. This is the second largest human-induced hypoxic zone worldwide, and varies in size from only $40 \mathrm{~km}^{2}$ due to the drought in 1988 to $22,730 \mathrm{~km}^{2}$ in 2017 5 .7 The Mississippi River/Gulf of Mexico Watershed Nutrient Task Force (Hypoxia Task Force) has set a goal of reducing the areal extent of the hypoxic zone to $<5000 \mathrm{~km}^{2}$ by the year $2035^{8}$, a substantial delay from the prior target date of $2015^{9}$. Although huge efforts and resources have been invested to reduce the amount of $\mathrm{N}$ delivered from the Basin to the Gulf, the size of the hypoxic zone in 2017 was the largest since $1985^{10}$, and 4.5 times the goal of $5000 \mathrm{~km}^{2}$.

The US EPA Science Advisory Board recommended that nutrient loading from the Basin must be reduced by at least $45 \%$ relative to the 1980-1996 average for reducing the hypoxic zone to $<5000 \mathrm{~km}^{2}$ in the Gulf ${ }^{11}$. An ensemble modeling study further pushed this target to a $59 \%$ reduction in current riverine $\mathrm{N}$ loads (Fig. 1) from the Basin under normal weather conditions ${ }^{12}$. Hydroclimate extremes (referring to drought and floods thereafter) make it even more challenging to achieve the goals in both crop production and environmental protection ${ }^{5,13,14}$. The degree of inter-annual variability of $\mathrm{N}$ loading from the Basin can vary by a factor of 2.3 (ratio of highest to lowest $\mathrm{N}$ loads), $76 \%$ of which has been attributed to variations of annual precipitation ${ }^{15}$. In addition, there is evidence for intense precipitation over the central US, with large increases in frequencies of "very heavy" and extreme precipitation events ${ }^{16}$. However, it remains uncertain to what extent extreme precipitation influences $\mathrm{N}$ yield (i.e., $\mathrm{N}$ leaching to local waters) and delivery to the Gulf. This uncertainty complicates the identification and adoption of effective $\mathrm{N}$ reduction practices in the face of extreme events.

Annual river discharge and $\mathrm{N}$ loads from the Basin have increased substantially since the $1950 \mathrm{~s}^{17-20}$, and precipitation changes in the twenty-first century are predicted to increase $\mathrm{N}$ loads by an additional $18 \%{ }^{21}$. Studies based on statistical models ${ }^{15,22}$ have identified correlations between $\mathrm{N}$ loading, net anthropogenic $\mathrm{N}$ input, and climate variations, but the underlying mechanisms responsible for these relationships are still not well clarified. Although a few empirical models ${ }^{23,24}$ have partially

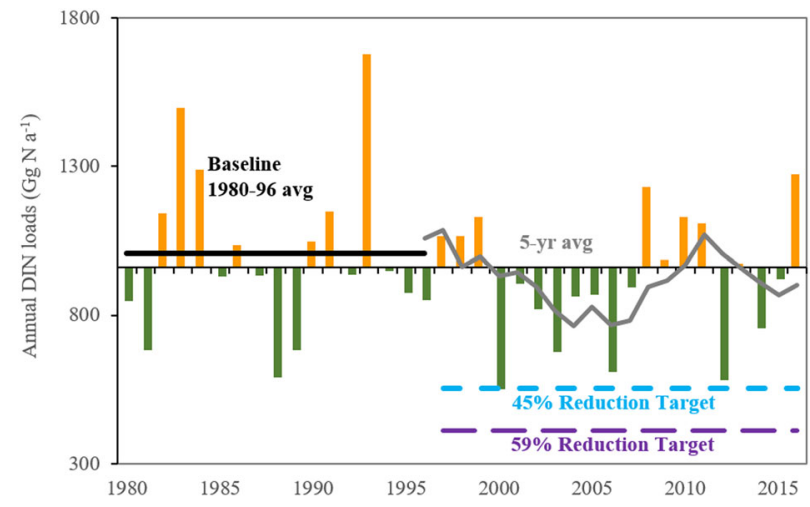

Fig. 1 Large inter-annual variations can be found in the monitored dissolved inorganic nitrogen (DIN) loads from the Mississippi and Atchafalaya river basin (MARB) to the Gulf of Mexico during 1980-2017. $X$-axis crosses $y$-axis at the 38 -year average $\left(961 \mathrm{Gg} \mathrm{N}_{\text {year }}{ }^{-1}\right.$ ). Annual values were calculated as the sum of $\mathrm{N}$ loading measured at the St. Francisville, LA (Station ID 07373420) and Melville, LA (station ID 07381495) by the USGS. accounted for mechanisms to explain the coupling between $\mathrm{N}$ load and hydroclimate, most of these models loosely couple the land-aquatic system, such that the climate sensitivity of $\mathrm{N}$ cycling and transport has been oversimplified and weakly verified ${ }^{15}$. Therefore, a better mechanistic understanding and quantification of $\mathrm{N}$ loads in response to hydroclimate extremes is imperative for improving management decision-making 25,26 . Here, we used a process-based hydro-ecological model, DLEM (Dynamic Land Ecosystem Model) ${ }^{26,27}$ that incorporates upland hydrological and biogeochemical processes along with the river system, to quantify the spatiotemporal patterns in riverine DIN loads (including $\mathrm{NH}_{4}-\mathrm{N}, \mathrm{NO}_{2}-\mathrm{N}$, and $\mathrm{NO}_{3}-\mathrm{N}$ ) from the Mississippi-Atchafalaya River Basin under extreme as well as non-extreme climate events. Our results indicate that extreme precipitation plays a growing role in yielding and delivering $\mathrm{N}$ across the Basin, and challenges $\mathrm{N}$ management practices in reducing $\mathrm{N}$ loading to the Gulf of Mexico.

\section{Results}

Intense precipitation in the Basin. We examined monthly and daily variations in hydroclimate extremes related to drought (based on the standard precipitation index (SPI)) and extreme precipitation (defined as daily precipitation amount above the 90th percentile for each 5 arc-min pixel) across the Basin since 1980. While severe drought (SPI $\leq-2.0$; Supplementary Fig. 1) was not detected in the 1980s and the 1990s, except in 1988, it occurred in 13\% of the Basin during the $2000 \mathrm{~s}$, and $8 \%$ in the 2010s. During the 2000s, $63 \%$ of the drainage area was exposed to drought (SPI $<0$ ), whereas this region was relatively wet in the 2010s, only $38 \%$ of the land area experienced drought. However, compared with 1980-1999, the share of extreme precipitation in annual total precipitation increased substantially across nearly two-thirds of the Basin during both the dry decade (2000s) and wet decade (2010s) (Fig. 2). On average, extreme precipitation contributed $32 \%$ of annual precipitation, and the areas receiving over $400 \mathrm{~mm}_{\text {year }}{ }^{-1}$ of accumulated extreme precipitation expanded from the middle and lower Mississippi river basins to the US Corn Belt, where $\mathrm{N}$ fertilizer was intensively used for promoting crop growth (Supplementary Fig. 2). Since 1980, 45-70\% of annual extreme precipitation in the Basin occurred in spring and summer, with a monthly peak in May (Supplementary Fig. 3), and extreme precipitation also increased in most sub-basins (Supplementary Fig. 4 and Supplementary Table 1). Over the past two decades, a consistent drying trend was found in the southern part of the Basin, in which, however, the amount of annual extreme precipitation still increased (Supplementary Fig. 1 and Supplementary Fig. 2).

Increasing contribution of extreme precipitation to $\mathrm{N}$ loads. The contribution of extreme precipitation events to water and $\mathrm{N}$ yield depends on when and where they occur and how severe they are. Using DLEM, we were able to quantify the degree of $\mathrm{N}$ loading in response to hydroclimate extremes. Our model estimates showed good agreements with US Geological Survey (USGS) gauge monitoring at multiple sites for monthly and annual total water discharge and $\mathrm{N}$ loads, as well as their monthly peaks (Supplementary Figs. 5-7). We also compared the daily modeled river discharge and $\mathrm{N}$ loading with the USGS raw measurements at the river outlets to the Gulf (Fig. 3 and Supplementary Fig. 8). They show that the model can well capture the inter-annual and intra-annual variations, and daily peaks in the observed water and $\mathrm{N}$ movement. We indeed found that this model may have overestimated the size of peak flows in a few extreme flooding events (such as floods in 2011, 2013, and 2016 as shown in Fig. 3), which is primarily attributed to the oversimplified flood control and dam operation processes in DLEM. 


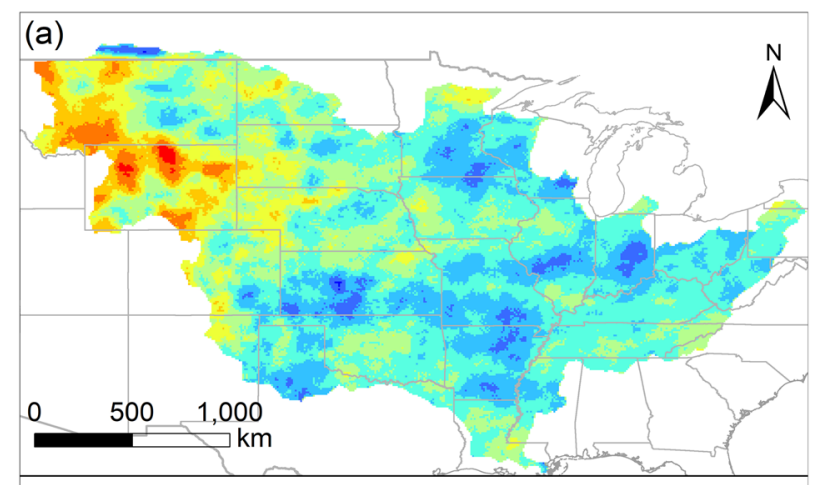

(b)

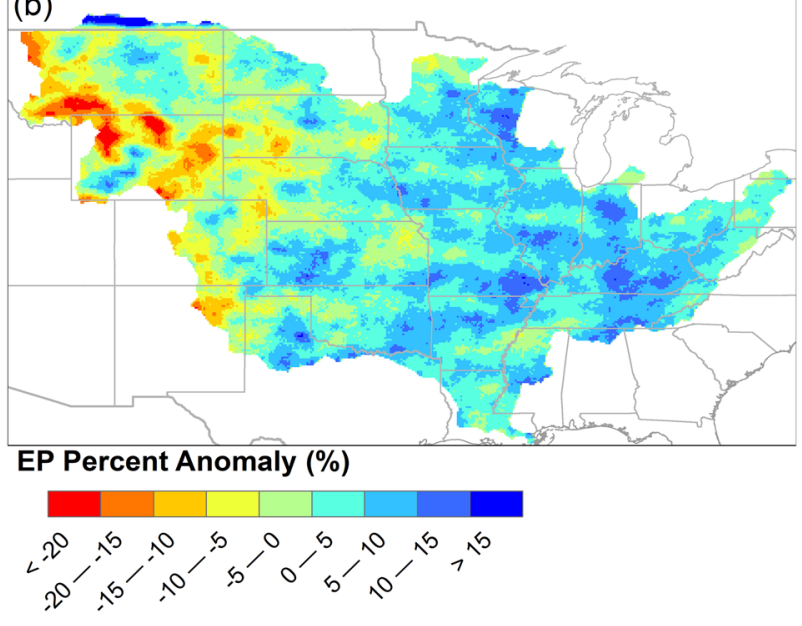

(c)

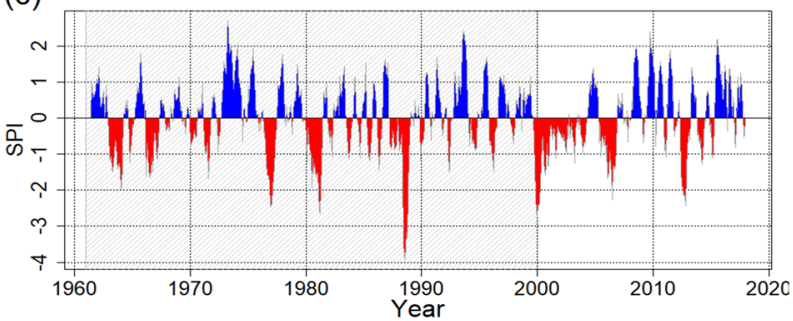

Fig. 2 Extreme precipitation percentage anomaly and drought severity across the Basin. Anomaly of extreme precipitation (EP) percentage to annual total precipitation across the Basin in the 2000s (a) and 2010s (b) relative to the period 1980-1999, and 24-month SPI (standard precipitation index) in this region during 1960-2017 (c). The 24-month SPI shows that the entire Basin experienced a persistent drought from late 1999 to 2005 , and 2007-2008.

However, this mismatch only occurs in limited events, and we therefore believe that it would not affect the major conclusion we draw from this study.

By setting up model experiments with and without climate variability, we distinguished and quantified how climate regulates $\mathrm{N}$ loads in this region. We found that climate-related variability (including precipitation, temperature, and shortwave radiation) has accounted for $76 \%$ and $72 \%$ of the monthly variations in river discharge and $\mathrm{N}$ loads from the Basin to the Gulf, respectively, since 1980 (Supplementary Fig. 9). Based on the USGS LOADEST and DLEM-modeled streamflow data at two near-coast sites, we identified those months with extremely high river flows using a functional data analysis approach (Supplementary Fig. 10). The LOADEST software is made available by the USGS for estimating constituent loads in streams and rivers based on a regression model given a time-series of streamflow, additional data variables, and constituent concentration (https://water.usgs.gov/software/ loadest/). The USGS LOADEST estimates show that, in these extremely high flow months, $\mathrm{N}$ load was, on average, 1.5 (1.1-1.7) times higher than the 38-year monthly median (Fig. 4a); our model estimates, which were $\sim 1.3(1.1-2.2)$ times higher than the median (Fig. 4b), show a comparable result. Both the USGS LOADEST and our modeling estimates support the view that extreme river flow coincides with substantially elevated $\mathrm{N}$ loads from the Basin to the Gulf when extreme precipitation occurs. The annual $\mathrm{N}$ load in years with extreme river flow months is on average 1.22-fold higher than the median of the 38-year USGS LOADEST estimates and 1.37-fold higher according to the DLEM model results. DLEM-estimated monthly $\mathrm{N}$ loads indeed display larger inter-annual variations, and lower median estimates of $\mathrm{N}$ loads in May and June than LOADEST estimations. We attribute this to two reasons: (1) DLEM may overestimate river discharge for extreme flooding events (as shown in Fig. 3) because we underrepresent the flooding control and dam operation processes; (2) the long-term rating curve used to gap-fill the infrequent nitrate concentration measurements may have overestimated $\mathrm{N}$ loading in regression models, like LOADEST, over an extended period (e.g., the regression-based $\mathrm{N}$ loading estimations are shown to exceed the observed loads by $25 \%$ or more at $33 \%$ of the 49 measurement sites of Iowa rivers ${ }^{28}$ ).

Basin-wide patterns of extreme precipitation contributions. For the entire Basin, decadal average water and $\mathrm{N}$ yield from the extreme precipitation days and their contributions to annual total yield increased in the past two decades despite large inter-annual variations. Extreme precipitation contribution to annual water yield was estimated to grow from $30 \%$ pre-2000 to $36 \%$ after 2000 , and its contribution to annual $\mathrm{N}$ yield increased from 28 to $34-35 \%$. This is equivalent to a net $\mathrm{N}$ yield increase of $114-156$ Gg $\mathrm{N}_{\text {year }}{ }^{-1}$ (Fig. 5 and Supplementary Table 2). However, additional model simulations revealed that the changes in $\mathrm{N}$ inputs (e.g., $\mathrm{N}$ fertilizer use, manure $\mathrm{N}$ application, and atmospheric $\mathrm{N}$ deposition), cropland area and rotations since 1980 had negligible contributions to these decadal shifts (Supplementary Table 2). Spatially, compared with the long-term (1980-2017) average, large areas in the Mississippi River Basin and the Ohio River Basin were shown to have negative anomalies of extreme precipitation contributions to annual water and $\mathrm{N}$ yield in the 1980 s and the 1990s (Fig. 5). Since the 2000s, the anomalies of extreme precipitation contribution in these areas have shifted from negative to positive, exceeding the long-term average by $10 \%$ or more. We also found that the areas characterized by increasing share of water and $\mathrm{N}$ yield in days with extreme precipitation have expanded to intensive cultivation and $\mathrm{N}$ application regions in the US Corn Belt. These findings highlight that extreme precipitation is playing a growing role in contributing to water and $\mathrm{N}$ loss in a large area of the Basin, and the US Corn Belt in particular during the 2000s.

We split the grid cells of the Basin into four groups by superimposing wetting and drying areas (detected by 24 -month SPI) with areas of increasing and declining amount of extreme precipitation (defined by the decadal extreme precipitation percent anomaly relative to the period 1980-1999). Spatially, $61 \%$ of the drainage area was characterized by increasing extreme precipitation in the 2000s with one half in drying areas and another half in wetting areas. In the 2010 s, however, $66 \%$ of the drainage area experienced increasing extreme precipitation, two-thirds of which became wetting (Fig. 6). We summed up that water yields and $\mathrm{N}$ yields occurred only in the extreme precipitation days as well as the annual total for these four groups of areas. Overall, $>80 \%$ of the Basin total runoff and $\mathrm{N}$ 

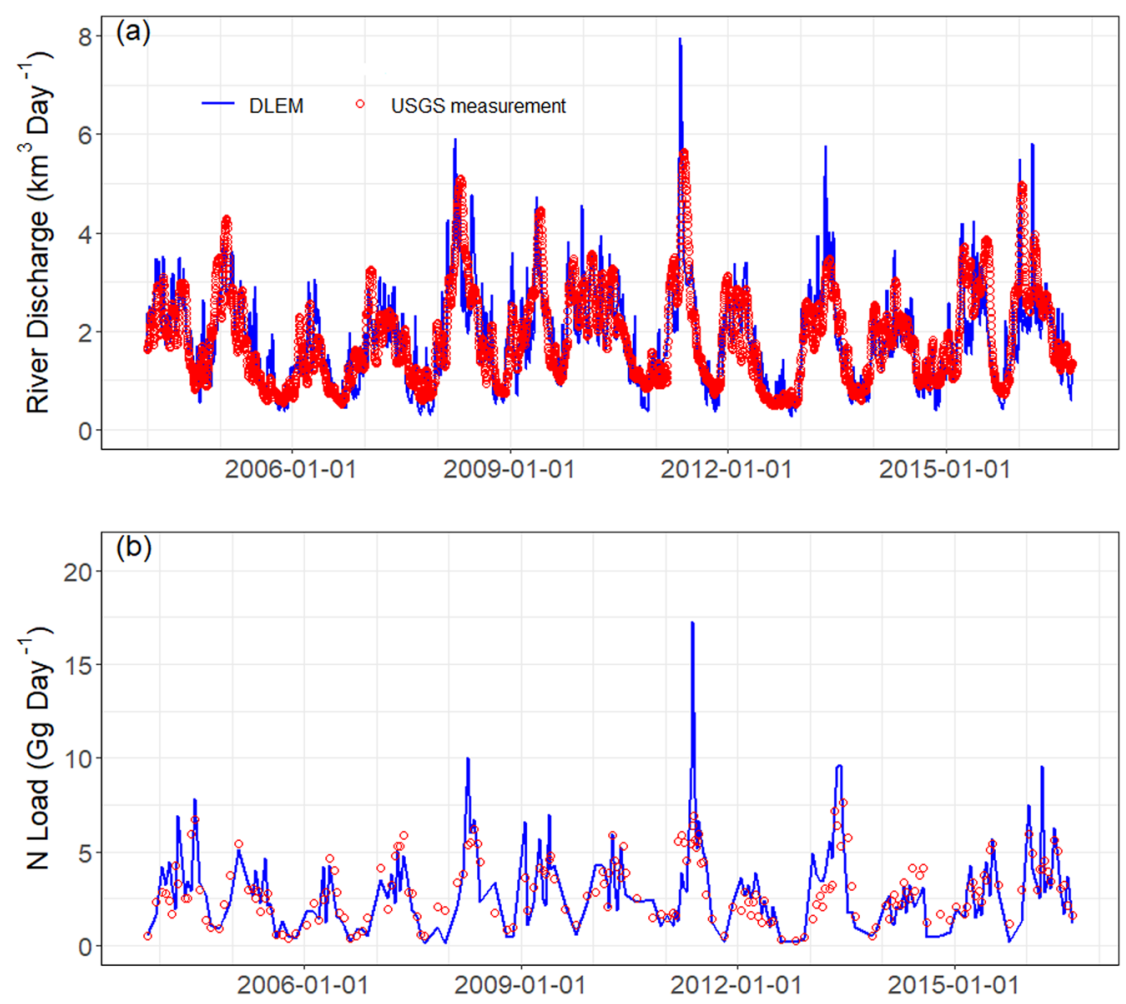

Fig. 3 Comparison of DLEM-modeled and USGS-monitored daily river discharge and $\mathbf{N}$ loading from the Basin. (a) The modeled and measured daily river discharge spanning from 1 April 2004 to 28 September 2016. (b) The modeled and measured daily N loading spanning from 28 October 2003 to 25 August 2016. The USGS river discharge was calculated based on the daily river discharge measurements at the Melville gauge station (statin ID 07381495) measuring the discharge of Atchafalaya River and at St. Francisville gauge station (07373420) measuring the discharge of the Mississippi River. The daily $\mathrm{N}$ loading measurements were also obtained from these two stations during the period 28 October 2003 to 25 August 2016, but are not continuous because flow- $\mathrm{N}$ concentration sampling was conducted at weekly or bi-weekly time step.

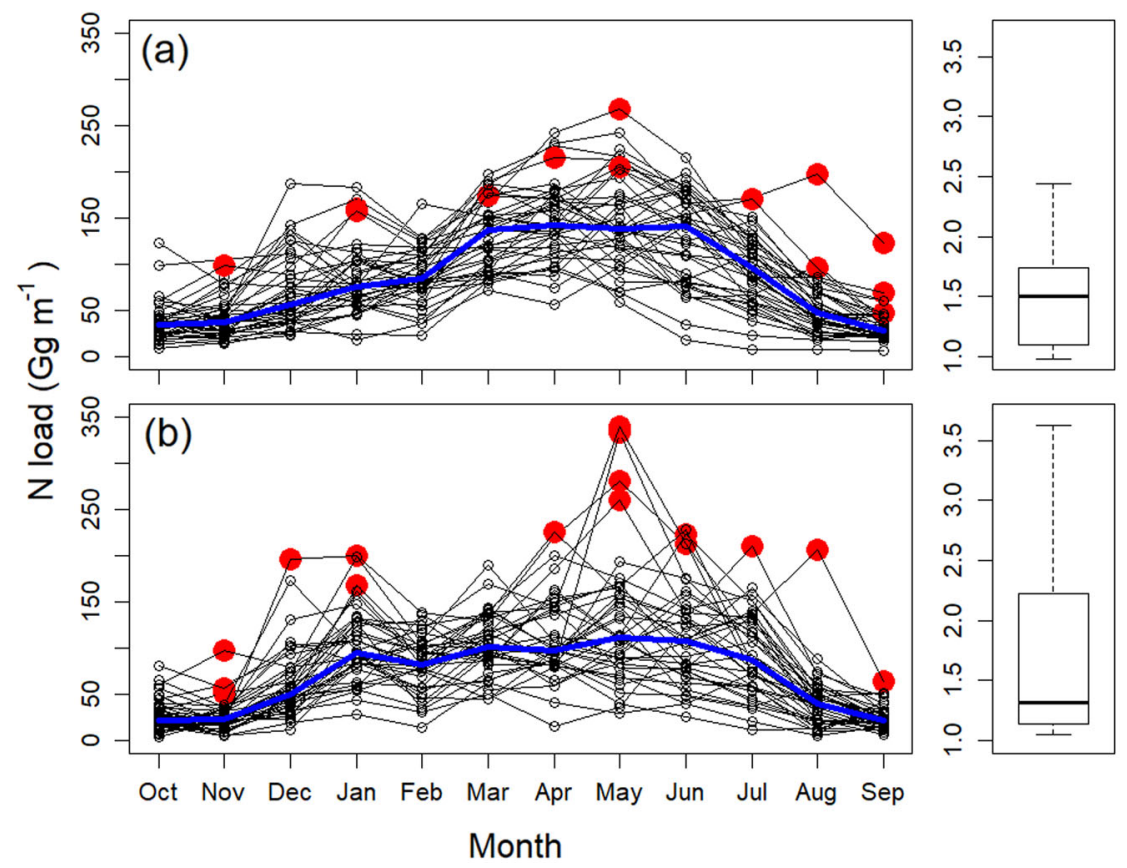

Fig. 4 Monthly N loads from the Mississippi-Atchafalaya River Basin to the Gulf of Mexico. (a) The sum of N load measured at St. Francisville (7373420) and Melville (7381495) during 1980-2017 as estimated by USGS LOADEST. (b) DLEM estimated N load during 1980-2017. Red circles are months with extreme river flows and the blue line is the median value for each month derived from the 38-year profile. The right panel indicates the deviations of $\mathrm{N}$ loads in the extreme flow months from monthly median values, with the black line and box indicating the mean and the 1st and 3rd quantile and the upper and lower whiskers indicating the maximum and minimum. 

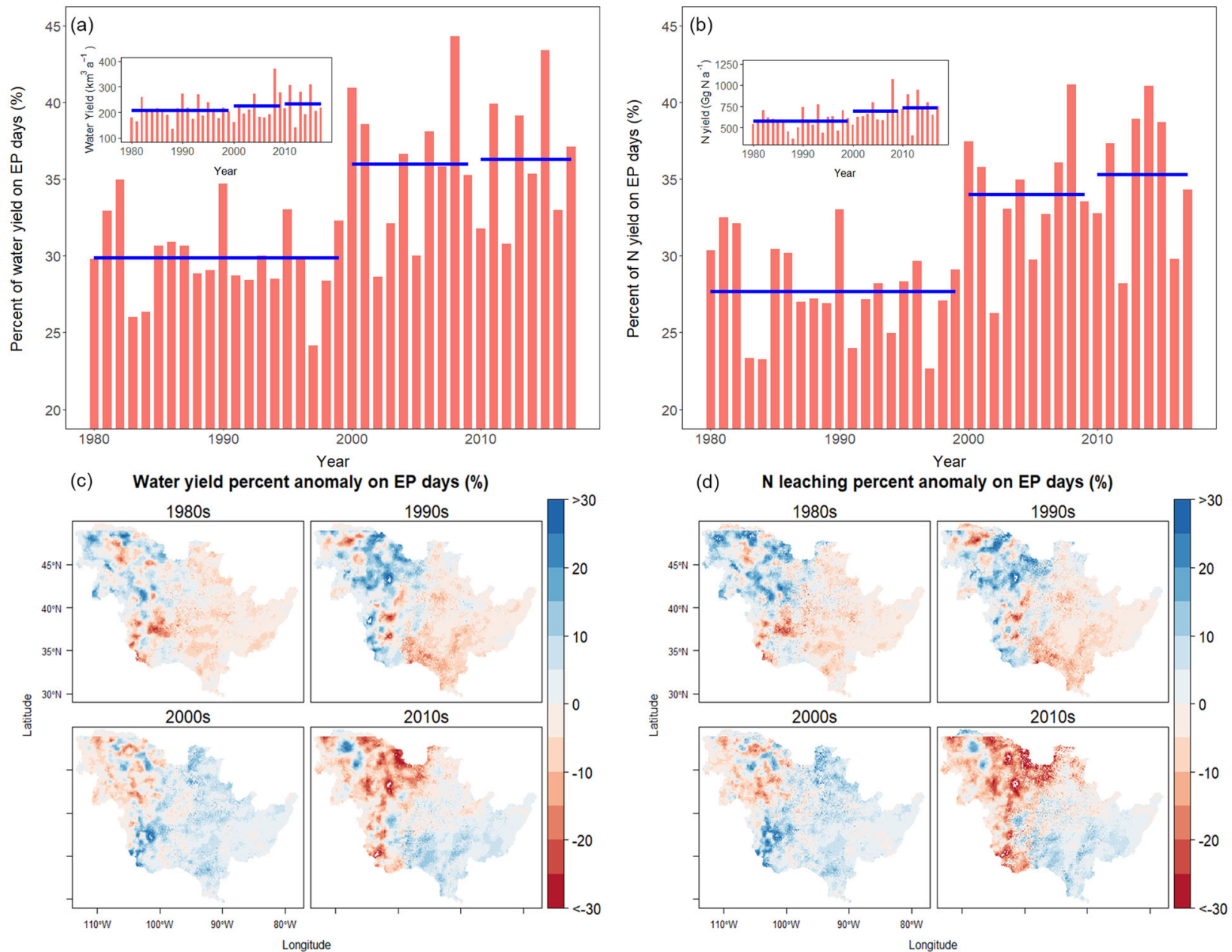

Fig. 5 The model-estimated water yield and $\mathbf{N}$ yield occurred in the days with extreme precipitation over the Basin during 1980-2017. The percentage of water yield (a) and $\mathrm{N}$ yield (b) occurred in the days with extreme precipitation (EP) relative to annual total in the Basin. The blue horizontal lines in $\mathbf{a}$, $\mathbf{b}$ represent the average of 1980-1999, the 2000s, and 2010s, respectively. The inset figures are the annual accumulative water and N yield during extreme precipitation days, and the horizontal lines represent the average of each period. The spatial maps indicate anomaly of extreme precipitation contribution to annual water yield (surface and sub-surface runoff) (c) and N yield (refers to N leaching to local waters) (d) compared with long-term (1980-2017) average across the MARB in each decade.

leaching was from the rising extreme precipitation areas. Basinwide, extreme precipitation events occurred only 8.6 days year ${ }^{-1}$ (2.4\% of 365 days) on average, but they contributed to approximately one-third of annual total water yields and $\mathrm{N}$ yields. This is likely a conservative estimate of the contribution of extreme precipitation events as we only focus on extreme precipitation days without consideration of post-event legacy effects.

In addition, we found extreme precipitation days played a more important role in the areas where drying climate occurred with increasing extreme precipitation (red area in Fig. 6a, b), contributing $38-43 \%$ (from the 2000s to 2010s) of annual water yield and $35-38 \%$ of annual $\mathrm{N}$ yield. In contrast, only $22-30 \%$ of annual water yield and $22-36 \%$ of annual $\mathrm{N}$ yield were from extreme precipitation days in the areas with declining extreme precipitation (yellow and green areas). Expanding areas suffered from heavy rainfall and the growing importance of such extreme events in yielding and delivering $\mathrm{N}$ to the Gulf make it even more challenging to reduce downstream $\mathrm{N}$ pollution through management practices in the upstream terrestrial ecosystems. The future risk of extreme flooding has been projected to increase in the lower Mississippi River ${ }^{29}$. Our study suggests that special attention should be paid to the effectiveness of $\mathrm{N}$ reduction practices during hydroclimate extreme events, extreme precipitation in particular.

Extreme precipitation and timing-sensitive $\mathbf{N}$ management. We used DLEM to "experimentally" test the effectiveness of changing the timing of $\mathrm{N}$ fertilizer application in reducing annual $\mathrm{N}$ loading during days with and without extreme precipitation. According to the USDA ARS survey and reconstructed maps of $\mathrm{N}$ fertilizer use $e^{30},>70 \%$ of fertilizer is applied to the Corn Belt in spring, most of which (92\%) is applied before crops are planted (mainly in March and April) and the remaining is applied at planting. Across the Basin, 22\% of annual total fertilizer is used in fall (usually after harvesting, September-November), leaving the after-planting (late May and June) fertilizer application to $<8 \%$. In our simulation experiments, instead of applying $\mathrm{N}$ fertilizer at the four traditional application timings following the USDA Economic Research Service state-level crop-specific survey ${ }^{30}$, we split the same amount of annual fertilizer use for each crop into two "after-planting" applications based on the growing degree units (GDUs) determined by the spatial location and local climate 


\section{(a) 2000s}

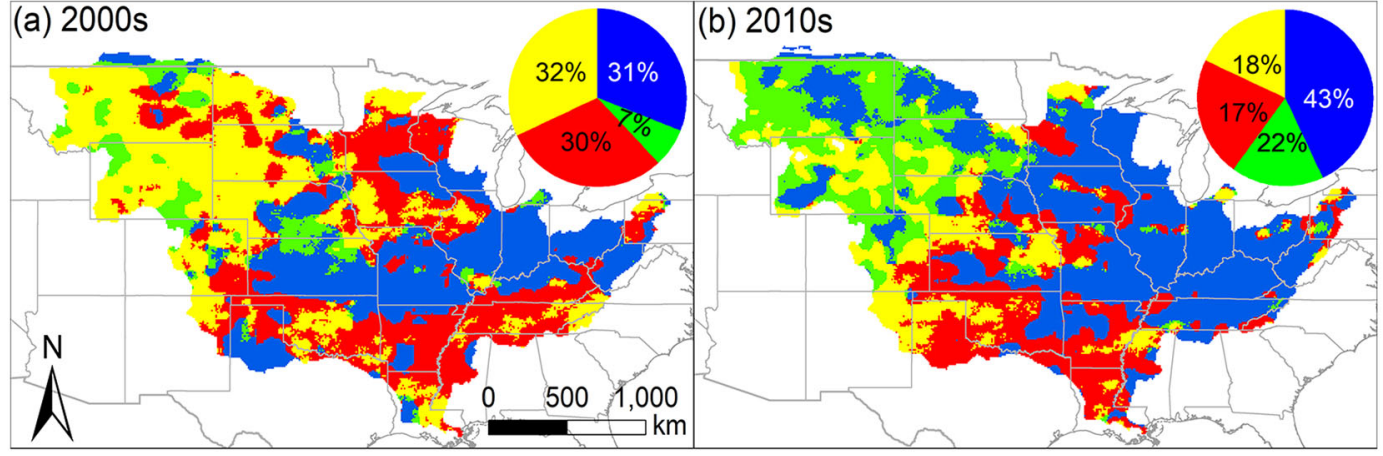

Drying + Rising EP Wetting + Rising EP

$\square$ Drying + Declining EP $\square$ Wetting + Declining EP
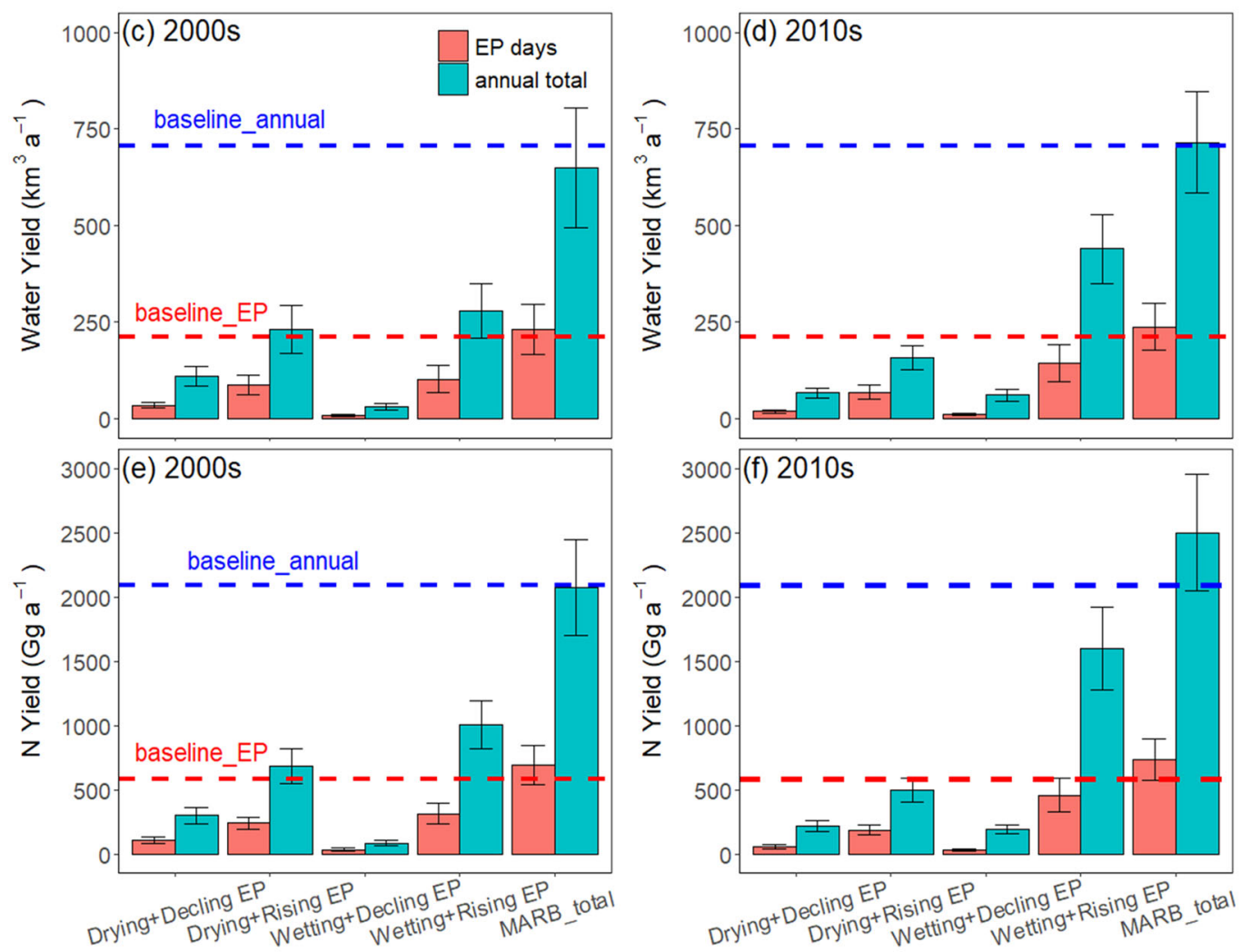

Fig. 6 Water yield and $\mathbf{N}$ yield in different precipitation categories across the Basin. Superimposition of trends in extreme precipitation (EP) and annual precipitation is used to spatially classify the grid cells of the Basin into four categories in the 2000s (a) and 2010s (b). The 24-month SPI was calculated for the 1980s to the 2010s. The average SPI of the period 1980-1999 was calculated as the baseline SPI. Drying and wetting trends were defined as negative and positive anomalies, respectively, of the SPI in the past two decades relative to the baseline SPI. The pie charts in $\mathbf{a}$, $\mathbf{b}$ represent the area percentage of each category in the entire Basin. The modeled water yield (i.e., the sum of surface and sub-surface runoff, $\mathbf{c}, \mathbf{d}$ ) and $\mathrm{N}$ yield (i.e., $\mathrm{N}$ leaching from soils, e, $\mathbf{f}$ ) in extreme precipitation days and the whole year averaged in the 2000s and the 2010s were summed for the four moisture groups in the Basin. The red and blue dashed lines in c-f represent the baseline average water and $\mathrm{N}$ yield in extreme precipitation days and the annual total during 1980-1999, respectively. The error bars (standard deviations) in $\mathbf{c}$, $\mathbf{d}$ and $\mathbf{e}, \mathbf{f}$, respectively, indicate the inter-annual variabilities of water yield and $\mathrm{N}$ yield over each decade under each category.

conditions (Fig. 7a). The "after-planting" fertilizer use was applied to all crop types but winter wheat. The modified fertilizer application timing is projected to effectively reduce annual $\mathrm{N}$ loads, except during June-October (Fig. 7b-d). On average, the reduction in $\mathrm{N}$ yield during non-extreme precipitation days accounted for two-thirds of the annual total reduction, leaving one-third to the extreme precipitation days. Our study shows that, compared with the USGS LOADEST baseline (1980-1996) $\mathrm{N}$ load, up to $16 \%$ of annual $\mathrm{N}$ load could be potentially reduced during $1980-2017$ by removing fall application and applying $\mathrm{N}$ fertilizer after planting (Fig. 7d), without harming the productivity of major crops (Fig. 7a and Supplementary Fig. 11). It is well within the range of the previously reported $\mathrm{N}$ loading reduction potentials in this region, for example, $5-20 \% \mathrm{~N}$ loading reduction (compared with 1980-1996 average) by replacing 5-25\% row crops with miscanthus or switchgrass across the Basin $^{31}$, and $11-55 \% \mathrm{~N}$ loading reduction by decreasing the basin-wide agricultural $\mathrm{N}$ surplus by $2050^{32}$.

With $\mathrm{N}$ fertilizer applied mutiple times after early crop development (mostly in May and June), the peak $\mathrm{N}$ load to the 

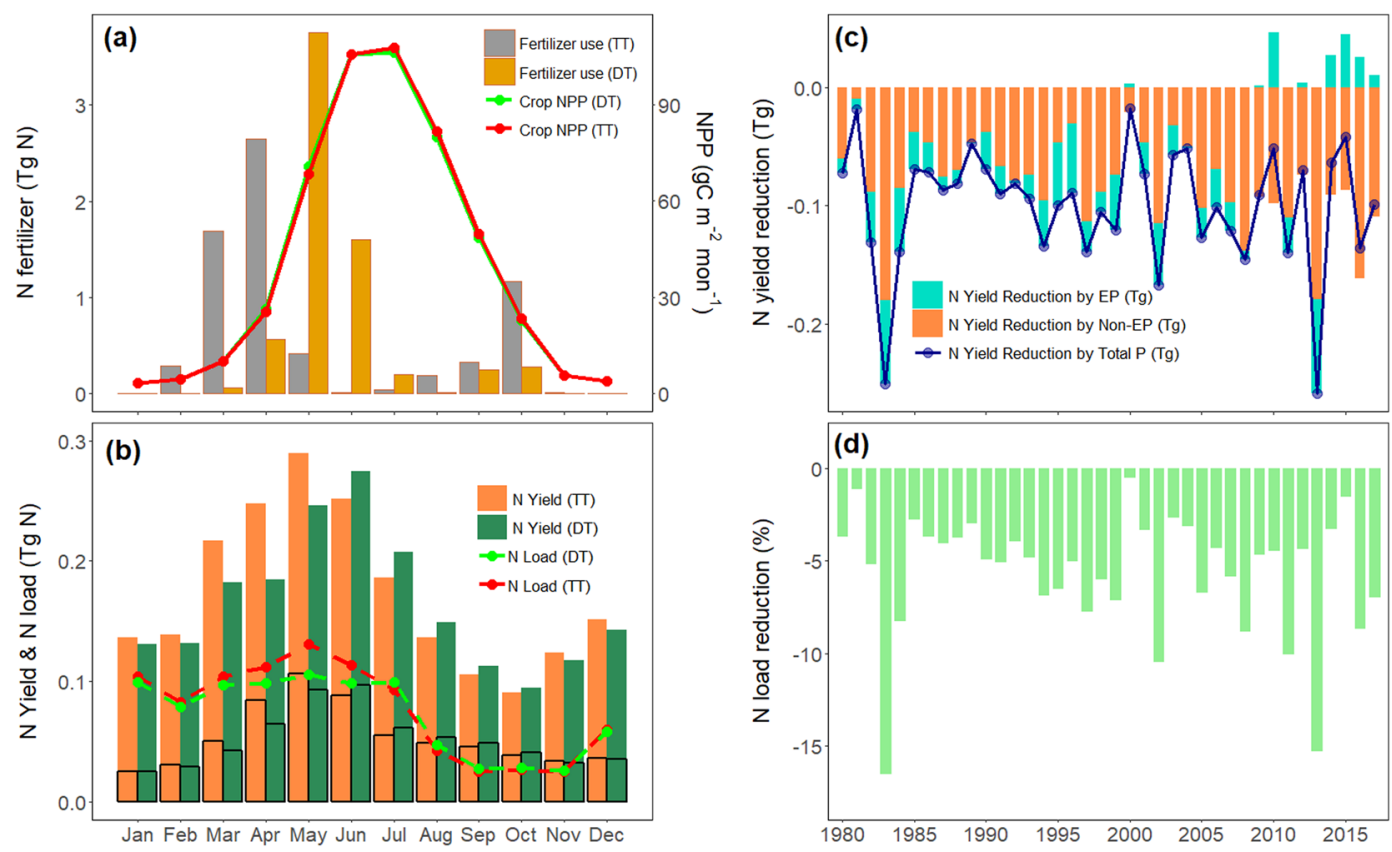

Fig. 7 The modeled effectiveness of changing $\mathbf{N}$ fertilizer application timing in reducing dissolved inorganic nitrogen (DIN) loads from the Basin to the Gulf. (a) Monthly $\mathrm{N}$ fertilizer use and the model-estimated crop net primary productivity (NPP) under traditional (TT) and dynamic/modified (DT) N fertilizer application timings in the Basin. (b) Model-estimated monthly $\mathrm{N}$ yield (i.e., $\mathrm{N}$ leaching from soils, calculated as a sum of all simulation grids) and load (i.e., N delivered to the Gulf, which is the model estimate at the outlet grid) under TT and DT N fertilizer use practices in the Basin. The black-outlined bars represent the amount of $\mathrm{N}$ yield that occurred during extreme precipitation days. (c) Nitrogen yield reduction by the dynamic fertilizer application on days with and without extreme precipitation (EP) during 1980-2017. The net annual reduction of $\mathrm{N}$ yield is represented by the dark-blue dotted line. (d) Model-estimated annual N load reduction at the Basin outlet to the Gulf of Mexico during 1980-2017 (reduction percentage is calculated as the difference in the annual $\mathrm{N}$ load estimates between TT and DT relative to the 1980-1996 baseline N load from USGS LOADEST).

Gulf is predicted to decline $19 \%$ (i.e., $0.03 \mathrm{Tg} \mathrm{N}_{\text {month }}{ }^{-1}$ in May; Fig. 7b). $\mathrm{N}$ yield reduction from March-May could reach 0.03-0.06 Tg N month ${ }^{-1}$ in the entire Basin, with extreme precipitation days responsible for just under a third of the total (Fig. 7b). However, we also found that the modified fertilizer application timing could enhance $\mathrm{N}$ delivery to surface waters during summer and early fall, with extreme precipitation days being very important-contributing $29-63 \%$ of the monthly $\mathrm{N}$ yield increase on average. The fertilizer timing change is predicted to lead to a net $\mathrm{N}$ yield increase during extreme precipitation events over multiple years of the 2010s, which is primarily caused by the growing contribution of extreme precipitation (Fig. 7c). Further modeling analysis also reveals that the alternative $\mathrm{N}$ fertilizer use timing has increased $\mathrm{N}$ yield in extreme precipitation days during June-October in the 2010s, while causing trivial differences in non-extreme precipitation days (Supplementary Fig. 12). It implies that the expected benefits of fertilizer application timing management will likely not be met during times of extreme precipitation. Although we indeed predict that a substantial $\mathrm{N}$ load reduction could be achieved by canceling excessive $\mathrm{N}$ input before crop $\mathrm{N}$ demand increases, these findings highlight assessing the effectiveness of $\mathrm{N}$ management practices along with occurrence of extreme precipitation. Before other strategies of reducing nitrogen load (e.g., assuming more agricultural areas use soybean-corn rotation and cover crops) are tested in our modeling framework, this study provides a starting point for regional analyses of how alternative $\mathrm{N}$ management practices could regulate nutrient loading during extreme climatic events, which is consistent with conclusions drawn from previous studies ${ }^{25,33,34}$.

Outlook. This study explicitly quantified the contribution of extreme precipitation days to $\mathrm{N}$ yield and loading in the
Mississippi-Atchafalaya River Basin. It also examined the potential for $\mathrm{N}$ load reduction using after-planting fertilizer applications and how extreme precipitation events can greatly diminish those reductions. The results of this study provide evidence that increasing amounts of extreme precipitation play a key role in driving inter-annual variations of $\mathrm{N}$ loads from the Basin to the Gulf of Mexico, making the already challenging goal of reducing hypoxia zone more difficult for management since the 2000s. However, we can still foresee potentials for reducing riverine $\mathrm{N}$ loads by mitigating the impacts of heavy rainfall. For instance, we may target enhancing long-term ecosystem $\mathrm{N}$ retention capability ${ }^{32}$, considering future precipitation change while making decisions for water quality management ${ }^{21}$, and modifying fertilizer input timing to meet plant nutrient demands while reducing the contribution of extreme precipitation events. We conclude that drought events and drying areas are also noteworthy since they may lead to an accumulation of available soil $\mathrm{N}$ that is readily mobilized while subsequent flooding events occur. Specifically, streamflow responses to precipitation increases were reported to have been amplified by human activities in the Midwestern US, due to enhanced hydrological connectivity, widespread artificial agricultural drainage, and increased area of agricultural land converted from grassland ${ }^{35}$. As climate models suggest that hydroclimate extremes may occur more frequently in the future $21,29,36$, our study demonstrates that managing $\mathrm{N}$ application timing could be an effective practice for reducing $\mathrm{N}$ load, but must take into account climate-related effects of extreme precipitation. There would be various management practices to be tested for their effectiveness, such as cover crops, wetland restoration, riparian buffers, and precision $\mathrm{N}$ management, and so on. Still, our conclusions drawn here have important ramifications regarding river basin nutrient management and reduction of eutrophication and hypoxia in the coasts. 


\section{Methods}

Data sources. Daily climate data (maximum, minimum, and mean temperature, precipitation, and shortwave radiation) used in this study were generated from high-resolution gridded meteorological data products from station observations by the Climatic Research Unit of the University of East Anglia ${ }^{37}$ and North America Regional Reanalysis dataset from a combination of modeled and observed data ${ }^{38}$. Atmospheric $\mathrm{CO}_{2}$ was retrieved from IPCC historical $\mathrm{CO}_{2}$ data and published data products ${ }^{39}$. The gridded $\mathrm{N}$ deposition data were developed by interpolating 3-year $\mathrm{N}$ deposition data with $\mathrm{N}$ emission patterns from $\operatorname{EDGAR}^{39,40}$. Land-use and land-cover change data used in this study were developed by $\mathrm{Yu}$ and $\mathrm{Lu}^{41}$, with the annual harvested crop area in each county kept consistent with the county-level survey records provided by USDA NASS. The time-series gridded data of $\mathrm{N}$ fertilizer use rate, timing, and types were developed by Cao et al. ${ }^{30}$. The details of model input data can be found in the Supplementary information (Part II). This study did not consider N source from wastewater because urban wastewater only contributes a small proportion of the total $\mathrm{N}$ loading into the Gulf of Mexico ${ }^{42}$.

Model validity in estimating streamflow and $\mathrm{N}$ load across the Basin was assessed by comparison with streamflow and nutrient flux measurements from the eight sub-basins (Supplementary Table 1) comprising the Mississippi-Atchafalaya River Basin provided by the US Geological Survey (https://toxics.usgs.gov/pubs/of2007-1080/flux.html). We also compared daily model outputs for the entire drainage basin with the measurements of streamflow and $\mathrm{N}$ load obtained near the outlets of Mississippi River and the Atchafalaya River in Louisiana (integration of St. Francisville and Melville sites) in order to validate the model outputs for the entire Basin. The USGS-derived monthly and annual riverine $\mathrm{NO}_{2}+\mathrm{NO}_{3}{ }^{-}-\mathrm{N}$ and $\mathrm{NH}_{4}{ }^{+}-\mathrm{N}$ loading data are based on the LOADEST software package (https://water. usgs.gov/software/loadest/). The details of model validations can be found in the Supplementary information (Part I, 1.2).

Definition of extreme precipitation. In this study, we define extreme precipitation days as the days with daily precipitation over the 90th percentiles in each month. This definition allows the spatial comparison across a large study area and accounts for the seasonality ${ }^{43}$. Specifically, the monthly 90 th percentiles are estimated using all daily precipitation from wet days (precipitation $\geq 1 \mathrm{~mm}$ ) in each month over a baseline period. We use a climatological baseline period 1961-1990 to estimate the thresholds for easy comparison with extreme climate indices ${ }^{44}$. Extreme precipitation is identified when the monthly 90th percentile threshold is surpassed at the grid cell level. The total extreme rainfall at each grid cell is calculated as the sum of all extreme precipitation days for a year.

Model simulations. In this study, we use an improved version of DLEM 2.0 that is capable of simulating $\mathrm{N}$ cycling and the flows of water and $\mathrm{N}$ from managed and natural land ecosystems (crops, grasslands, forests, etc.) to streams and rivers across the entire Mississippi-Atchafalaya River Basin. This version of DLEM was developed to explicitly model the coupled carbon-nitrogen-water cycles within a plant-soil-water-river continuum ${ }^{45-48}$. In DLEM, each grid cell is a cohort of up to four natural plant functional types and one cropping system with its annual area percentage prescribed by land-use input data. Specifically, we consider the distribution and physiological properties of corn, soybean, winter wheat, spring wheat, rice, and six other major crop types across the river basin. This version of DLEM also models management practices including synthetic $\mathrm{N}$ fertilizer and manure applications, tile drainage, tillage, crop rotation, and effects of crop technology innovations for agricultural systems, as well as the effects of climate, $\mathrm{CO}_{2}$, and nitrogen deposition for both natural and managed ecosystems. The detailed information of these factors can be found in the Supplementary information (Part II, 2.2-2.4).

Surface runoff and baseflow routing and river networks are integrated into $\mathrm{DLEM}^{49}$. The simulation experiment forced by all transient climate, management, and environmental drivers were used to represent our "best estimate" of land-to-aquatic DIN loads (including $\mathrm{NH}_{4}-\mathrm{N}, \mathrm{NO}_{2}-\mathrm{N}$, and $\mathrm{NO}_{3}-\mathrm{N}$ ) across the Basin, which refers to simulation 1 (S1). To account for the effects of climate variability on water and $\mathrm{N}$ yield, we used a second simulation, S2, which incorporates all transient input data variations from 1900 to 2017 but holds climate data constant at a 30-year average level during 1981-2017. The longterm average climate data were developed by applying the 30 -year average climatology from 1961 to 1990 to the daily pattern of 1982, during which the least extreme climate events were recorded ${ }^{50}$. The effects of climate on water and $\mathrm{N}$ delivery were estimated as the difference between S1 and S2. In this study, we quantified $\mathrm{N}$ leaching to local waters at each simulation grid as $\mathrm{N}$ yield (in a unit of $\mathrm{g} \mathrm{N} \mathrm{m}^{-2} \mathrm{day}^{-1}$ ) and accumulated $\mathrm{N}$ delivered to rivers and coastal areas at the river outlet grids as $\mathrm{N}$ load (in a unit of $\mathrm{Tg} \mathrm{N} \mathrm{day}^{-1}$ ). As the occurrence of extreme precipitation was identified specific to each grid, we only provide an estimate of extreme precipitation contribution to $\mathrm{N}$ yield, rather than $\mathrm{N}$ load. Daily estimates were aggregated to monthly and annual total for analysis and comparison purposes. The detailed information of the representation of $\mathrm{N}$ leaching, transfer and delivery in DLEM can be found in the Supplementary information (Part III, 3.1).
In addition to the above simulation experiments, we performed two additional experiments to illustrate the contributions of changing $\mathrm{N}$ input sources to $\mathrm{N}$ yield during extreme precipitation events with (S3) and without (S4) consideration of land-use and land-cover changes plus crop rotation. In experiment $\mathrm{S} 3$, we held only $\mathrm{N}$ input rates (including $\mathrm{N}$ fertilizer use, atmospheric $\mathrm{N}$ deposition, and manure $\mathrm{N}$ application) constant at the level of 1980 for the post-1980 period while allowing annual changes in land-use pattern and crop rotations based on prescribed input database. In experiment $\mathrm{S} 4$, we held $\mathrm{N}$ input, land use, and crop rotation constant at the level of 1980 for the post-1980 period. All the rest input drivers such as climate and atmospheric $\mathrm{CO}_{2}$ concentration were allowed to change in these two simulations. The differences between the all-drivers-on simulation (S1) and these two simulations respectively represent the contributions of the changing $\mathrm{N}$ input rates on per unit land area and the contributions of $\mathrm{N}$ input rates plus cropland expansion and abandonment as well as crop rotation (because total $\mathrm{N}$ inputs are affected by cropland area and crop types planted in each grid cell in each year). We did not partition crop rotation with land-use and land-cover change because they together determine how much $\mathrm{N}$ fertilizer was applied in a specific region.

Modification of fertilizer application timings. To test whether fertilizer management can reduce $\mathrm{N}$ load given enhanced extreme rainfall events, we developed a dynamic N fertilizer use scheme for DLEM and implemented the fifth model simulation, S5. Considering that corn is the dominant crop type (Supplementary Fig. 13) and is associated with the largest consumption of $\mathrm{N}$ fertilizer throughout the entire river basin (Supplementary Figs. 14 and 15), we used growth phases of corn as a proxy for all the crops to examine the impact of fertilizer application timing ${ }^{51}$. The total $\mathrm{N}$ fertilizer amount remains the same as the traditional $\mathrm{N}$ application practice used for simulation S1. Specifically, we input $\mathrm{N}$ fertilizer twice per year, referring to V1 (the plant phase for which the first leaf has fully emerged) and V5 (the phase at which the collar of the fifth leaf is visible) growth phases of corn. Each fertilizer application shares $50 \%$ of the annual total. The growth phases of corn are determined by the GDUs. The GDU values range from 232 to 282 and from 496 to 546 when corn reaches V1 and V5 phases, respectively ${ }^{52}$. The peak $\mathrm{N}$ fertilizer input is postponed from April to late May (Fig. 7). We note that the dynamic $\mathrm{N}$ fertilization scheme does not apply to winter wheat due to its unique growth phenology. The $\mathrm{N}$ load reduction resulting from the dynamic $\mathrm{N}$ fertilization scheme is estimated by the difference between simulations S1 (traditional timing, TT) and S5 (dynamic timing, DT). The detailed information of dynamic $\mathrm{N}$ fertilizer use scheme can be found in the Supplementary information (Part III, 3.2).

\section{Data availability}

Model estimates of water yield and $\mathrm{N}$ yield across the Basin, which were used to produce the major findings in this article, are available at https://doi.org/10.25380/iastate.12779954.

\section{Code availability}

The availability of DLEM model code used to conclude the findings of this study is upon special requests (contact: clu@iastate.edu and tianhan@auburn.edu). The code of the "Functional Boxplot" used to detect the historical months with extreme river discharge can be found in the "fda" v5.1.4 R package that is available at https://www. rdocumentation.org/packages/fda.

Received: 10 February 2020; Accepted: 19 August 2020; Published online: 18 September 2020

\section{References}

1. Dunn, D. E. Trends in Nutrient Inflows to the Gulf of Mexico from Streams Draining the Conterminous United States, 1972-1993 (US Geological Survey, 1996).

2. Goolsby, D. A., Battaglin, W. A., Aulenbach, B. T. \& Hooper, R. P. Nitrogen flux and sources in the Mississippi River Basin. Sci. Total Environ. 248, 75-86 (2000).

3. Rabalais, N. N. et al. Hypoxia in the northern Gulf of Mexico: does the science support the plan to reduce, mitigate, and control hypoxia? Estuar. Coasts https://doi.org/10.1007/BF02841332 (2007).

4. David, M. B., Drinkwater, L. E. \& McIsaac, G. F. Sources of nitrate yields in the Mississippi River Basin. J. Environ. Qual. https://doi.org/10.2134/ jeq2010.0115 (2010).

5. Rabalais, N. N., Turner, R. E., Wiseman, J., William, J. \& Dortch, Q. Consequences of the 1993 Mississippi River flood in the Gulf of Mexico. Regul. Rivers Res. Manag. 14, 161-177 (1998).

6. Scavia, D., Rabalais, N. N., Turner, R. E., Justić, D., Wiseman, W. J. Predicting the response of Gulf of Mexico hypoxia to variations in Mississippi River nitrogen load. Limnol. Oceanogr. https://doi.org/10.4319/lo.2003.48.3.0951 (2003). 
7. Turner, R. E., Rabalais, N. N. \& Justic, D. Predicting summer hypoxia in the northern Gulf of Mexico: Riverine N, P, and Si loading. Mar. Pollut. Bull. 52, 139-148 (2006).

8. US Environmental Protection Agency. Action Plan for Reducing, Mitigating and Controlling Hypoxia in the Northern Gulf of Mexico (Office of Wetlands, Oceans, and Watersheds, US Environmental Protection Agency, 2001).

9. US Environmental Protection Agency. Mississippi River/Gulf of Mexico Watershed Nutrient Task Force: 2015 Report to Congress (US Environmental Protection Agency, 2015)

10. US Environmental Protection Agency. Mississippi River/Gulf of Mexico Hypoxia Task Force, Northern Gulf of Mexico Hypoxic Zone. https://www.epa. gov/ms-htf/northern-gulf-mexico-hypoxic-zone (2020).

11. US Environmental Protection Agency. Hypoxia in the Northern Gulf of Mexico: An Update by the EPA, Scientific Advisory Board (US Environmental Protection Agency, 2007).

12. Scavia, D. et al. Ensemble modeling informs hypoxia management in the northern Gulf of Mexico. Proc. Natl. Acad. Sci. USA. https://doi.org/10.1073/ pnas.1705293114 (2017).

13. Donner, S. D. \& Scavia, D. How climate controls the flux of nitrogen by the Mississippi River and the development of hypoxia in the Gulf of Mexico. Limnol. Oceanogr. https://doi.org/10.4319/lo.2007.52.2.0856 (2007).

14. Murdoch, P. S., Baron, J. S. \& Miller, T. L. Potential effects of climate change on surface-water quality in North America. J. Am. Water Resour. Assoc. https://doi.org/10.1111/j.1752-1688.2000.tb04273.x (2000).

15. Sinha, E. \& Michalak, A. M. Precipitation dominates interannual variability of riverine nitrogen loading across the continental United States. Environ. Sci. Technol. https://doi.org/10.1021/acs.est.6b04455 (2016).

16. Groisman, P. Y., Knight, R. W. \& Karl, T. R. Changes in intense precipitation over the central United States. J. Hydrometeorol 13, 47-66 (2012).

17. Bratkovich, A., Dinnel, S. P. \& Goolsby, D. A. Variability and prediction of freshwater and nitrate fluxes for the Louisiana-Texas shelf: Mississippi and Atchafalaya River source functions. Estuaries 17, 766-778 (1994).

18. Rabalais, N. N., Turner, R. E. \& Scavia, D. Beyond Science into Policy: Gulf of Mexico Hypoxia and the Mississippi River Nutrient policy development for the Mississippi River watershed reflects the accumulated scientific evidence that the increase in nitrogen loading is the primary factor in the wo. Bioscience 52, 129-142 (2002).

19. Rabalais, N. N., Atilla, N., Normandeau, C. \& Eugene Turner, R. Ecosystem history of Mississippi River-influenced continental shelf revealed through preserved phytoplankton pigments. Mar. Pollut. Bull. https://doi.org/10.1016/ j.marpolbul.2004.03.017 (2004).

20. Tian, H. et al. Long-term trajectory of nitrogen loading and delivery from Mississippi River Basin to the Gulf of Mexico. Global Biogeochem. Cycles 34, e2019GB006475 (2020).

21. Sinha, E., Michalak, A. M. \& Balaji, V. Eutrophication will increase during the 21 st century as a result of precipitation changes. Science 357, 405-408 (2017).

22. Howarth, R. et al. Nitrogen fluxes from the landscape are controlled by net anthropogenic nitrogen inputs and by climate. Front. Ecol. Environ. 10, 37-43 (2012).

23. Smith, R. A., Schwarz, G. E. \& Alexander, R. B. Regional interpretation of water-quality monitoring data. Water Resour. Res. https://doi.org/10.1029/ 97WR02171 (1997).

24. Robertson, D. M., Saad, D. A. \& Schwarz, G. E. Spatial variability in nutrient transport by HUC 8, state, and subbasin based on Mississippi/Atchafalaya River Basin SPARROW Models. J. Am. Water Resour. Assoc. 50, 988-1009 (2014).

25. Lee, M., Shevliakova, E., Malyshev, S., Milly, P. C. D. \& Jaffé, P. R. Climate variability and extremes, interacting with nitrogen storage, amplify eutrophication risk. Geophys. Res. Lett. https://doi.org/10.1002/2016GL069254 (2016).

26. Yang, Q. et al. Increased nitrogen export from eastern North America to the Atlantic Ocean due to climatic and anthropogenic changes during 1901-2008. J. Geophys. Res. Biogeosci. 120, 757-772 (2015).

27. Tian, H. et al. Climate extremes dominating seasonal and interannual variations in carbon export from the Mississippi River Basin. Global Biogeochem. Cycles 29, 1333-1347 (2015).

28. Stenback, G. A., Crumpton, W. G., Schilling, K. E. \& Helmers, M. J. Rating curve estimation of nutrient loads in Iowa rivers. J. Hydrol. 396, 158-169 (2011).

29. Munoz, S. E. \& Dee, S. G. El Niño increases the risk of lower Mississippi River flooding. Sci. Rep. https://doi.org/10.1038/s41598-017 01919-6 (2017)

30. Cao, P., Lu, C. \& Yu, Z. Historical nitrogen fertilizer use in agricultural ecosystems of the contiguous United States during 1850-2015: application rate, timing, and fertilizer types. Earth Syst. Sci. Data 10, 969 (2018).

31. VanLoocke, A., Twine, T. E., Kucharik, C. J. \& Bernacchi, C. J. Assessing the potential to decrease the Gulf of Mexico hypoxic zone with Midwest US perennial cellulosic feedstock production. GCB Bioenergy 9, 858-875 (2017).

32. Van Meter, K. J., Van Cappellen, P. \& Basu, N. B. Legacy nitrogen may prevent achievement of water quality goals in the Gulf of Mexico. Science https://doi.org/10.1126/science.aar4462 (2018).

33. Nangia, V., Gowda, P. H. \& Mulla, D. J. Effects of changes in N-fertilizer management on water quality trends at the watershed scale. Agric. Water Manag. https://doi.org/10.1016/j.agwat.2010.06.023 (2010).

34. Nangia, V., Mulla, D. J. \& Gowda, P. H. Precipitation changes impact stream discharge, nitrate-nitrogen load more than agricultural management changes. J. Environ. Qual. https://doi.org/10.2134/jeq2010.0105 (2010).

35. Kelly, S. A., Takbiri, Z., Belmont, P. \& Foufoula-Georgiou, E. Human amplified changes in precipitation-runoff patterns in large river basins of the Midwestern United States. Hydrol. Earth Syst. Sci. https://doi.org/10.5194/ hess-21-5065-2017 (2017).

36. Field, C. B. et al. Managing the Risks of Extreme Events and Disasters to Advance Climate Change Adaptation: Special Report of the Intergovernmental Panel on Climate Change (Cambridge University Press, 2012).

37. Mitchell, T. D. \& Jones, P. D. An improved method of constructing a database of monthly climate observations and associated high-resolution grids. Int. J. Climatol. 25, 693-712 (2005).

38. Mesinger, F. et al. North American regional reanalysis. Bull. Am. Meteorol. Soc. 87, 343-360 (2006)

39. Wei, Y. et al. The north american carbon program multi-scale synthesis and terrestrial model intercomparison project-Part 2: environmental driver data Geosci. Model Dev. 7, 2875-2893 (2014)

40. Dentener, F. J. Global Maps of Atmospheric Nitrogen Deposition, 1860, 1993 and 2050. Data Set (Oak Ridge Natl. Lab. Distrib. Act. Arch. Center, Oak Ridge, 2006).

41. Yu, Z. \& Lu, C. Historical cropland expansion and abandonment in the continental US during 1850 to 2016. Glob. Ecol. Biogeogr. 27, 322-333 (2018).

42. Robertson, D. M. \& Saad, D. A. SPARROW models used to understand nutrient sources in the Mississippi/Atchafalaya River Basin. J. Environ. Qual 42, 1422-1440 (2013).

43. Zhang, J., Felzer, B. S. \& Troy, T. J. Extreme precipitation drives groundwater recharge: the Northern High Plains Aquifer, central United States, 1950-2010. Hydrol. Process. 30, 2533-2545 (2016).

44. Zhang, X., Hegerl, G., Zwiers, F. W. \& Kenyon, J. Avoiding inhomogeneity in percentile-based indices of temperature extremes. J. Clim. 18, 1641-1651 (2005).

45. Chen, G. et al. Climate Impacts on China's Terrestrial Carbon Cycle: An Assessment with the Dynamic Land Ecosystem Model. In: Environmental Modeling and Simulation (ed Tian, H. Q.), pp. 56-70. (ACTA Press, Calgary, 2006).

46. Liu, M. et al. Effects of land-use and land-cover change on evapotranspiration and water yield in China during 1900-2000 1. J. Am. Water Resour. Assoc. 44 1193-1207 (2008)

47. Tian, H. et al. Spatial and temporal patterns of $\mathrm{CH} 4$ and N2O fluxes in terrestrial ecosystems of North America during 1979-2008: application of a global biogeochemistry model. Biogeosciences 7, 2673-2694 (2010).

48. Lu, C. et al. Increasing carbon footprint of grain crop production in the US Western Corn Belt. Environ. Res. Lett. 13, 124007 (2018).

49. Liu, M. et al. Long-term trends in evapotranspiration and runoff over the drainage basins of the Gulf of Mexico during 1901-2008. Water Resour. Res. 49, 1988-2012 (2013).

50. Ross, T. \& Lott, N. A Climatology of 1980-2003 Extreme Weather and Climate Events. National Climatic Data Center Technical Report No. 2003-01 (NOAA/ NationalClimatic Data Center, Asheville, 2003).

51. Timmons, D. R. \& Baker, J. L. Recovery of point-injected labeled nitrogen by corn as affected by timing, rate, and tillage. Agron. J. 83, 850-857 (1991)

52. Hanway, J. J. How a Corn Plant Develops. Special Report, 38 (Iowa State University, Cooperative Extension Service, 1966).

\section{Acknowledgements}

This work is supported partially by Iowa Nutrient Research Center, new-faculty startup fund of Iowa State University, NSF Grant (1903722), NSF CAREER (1945036), NASA Grant (NNX14AO73G), and NOAA Grant (NA16NOS4780204).

\section{Author contributions}

C.L. designed the experiments, C.L. and J.Z. implemented model simulations, analyzed the data, and wrote the manuscript; all authors discussed the results and interpreted the model data, and contributed to the final manuscript. 


\section{Competing interests}

The authors declare no competing interests.

\section{Additional information}

Supplementary information is available for this paper at https://doi.org/10.1038/s43247020-00020-7

Correspondence and requests for materials should be addressed to C.L.

Peer review information Primary handling editor Joe Aslin.

Reprints and permission information is available at http://www.nature.com/reprints

Publisher's note Springer Nature remains neutral with regard to jurisdictional claims in published maps and institutional affiliations. (c) (i) Open Access This article is licensed under a Creative Commons Attribution 4.0 International License, which permits use, sharing, adaptation, distribution and reproduction in any medium or format, as long as you give appropriate credit to the original author(s) and the source, provide a link to the Creative Commons license, and indicate if changes were made. The images or other third party material in this article are included in the article's Creative Commons license, unless indicated otherwise in a credit line to the material. If material is not included in the article's Creative Commons license and your intended use is not permitted by statutory regulation or exceeds the permitted use, you will need to obtain permission directly from the copyright holder. To view a copy of this license, visit http://creativecommons.org/ licenses/by/4.0/.

(C) The Author(s) 2020 